\title{
Prunus (Amygdalaceae) in New South Wales
}

\author{
J.M.B. Smith
}

\begin{abstract}
Smith, J.M.B. (Dept. of Geography and Planning, University of New England, Armidale, Australia 2351) 1988. Prunus (Amygdalaceae) in New South Wales. Telopea 3(2): 145-157. - Thirteen introduced species of Prunus occur in New South Wales, and are described from material collected from wild individuals in the State. Four or five are in process of becoming naturalized. Dispersal, distribution and phenology, and the taxonomy of plums, are discussed. A key to the species, subspecies and varieties is provided.
\end{abstract}

\section{Introduction}

While native species of Prunus L. (subgenus Laurocerasus) are found in New Guinea and north Queensland rainforests, all species in New South Wales have been introduced. It is a nearly cosmopolitan genus of some 430 species (Willis 1966). Many species have been cultivated widely in temperate regions for several centuries. As a result, and because hybrids are also common, the taxonomy of the genus is well studied but complex, and variously interpreted. The taxonomic units used here generally follow those in 'Flora Europea' (Tutin et al. 1968).

In this paper all Prunus species known to occur as wild plants in New South Wales are considered. However, like most introduced plants in Australia, their collection and study have been generally neglected, and specimens are few. Jacobs and Pickard (1981) listed $P$. cerasifera, $P$. lusitanica, $P$. persica and $P$. serotina as having been collected in the State, but only for $P$. persica did specimens come from more than one region. My own fieldwork has been conducted principally in northeast New South Wales since 1980; especially in other areas, it is possible that further Prunus species occur at least occasionally as wild plants, without yet having been collected or recorded.

No Prunus species were listed by Anderson (1939) as being naturalized in New South Wales up to that time; later regional floras (e.g. Beadle 1976; Beadle, Evans \& Carolin 1972; Burbidge \& Gray 1970) also make no mention of Prunus except as cultivated plants. However in Victoria, Willis (1972) considered $P$. cerasifera to be truly naturalized, and mentioned $P$. armeniaca, $P$. cerasus, $P$. dulcis (as $P$. amygdalus), $P$. laurocerasus and $P$. persica as sometimes appearing where stones or kernels had been discarded from the fruits of various cultivars. Lord (1964) noted that $P$. cerasifera was frequently selfsown in southeast Australian gardens or nearby. In Tasmania, Curtis (1956) described $P$. domestica subsp. insititia (as $P$. insititia) as an established alien, occasional in hedges and widespread. In South Australia, Eichler (1965) noted that several cultivated species of Rosaceae were established and becoming naturalized, mainly in the Mount Lofty Ranges, and cited specimens of $P$. cerasifera, $P$. cerasus, $P$. domestica, $P$. dulcis (as $P$. amygdalus), $P$. laurocerasus and $P$. persica. 
In the present paper, thirteen Prunus species are recorded and described from wild plants in New South Wales, of which four or five may be considered to be in process of becoming naturalized, one widely and commonly. They are of some significance as potential uncontrolled reservoirs of orchard pest and disease organisms, as well as being sources of fruit collected wild, and of aesthetic value when in conspicuous white or pink blossom in spring.

\section{Distribution, Dispersal and Naturalization}

Prunus has been planted in New South Wales widely and for several reasons. $P$. persica (Peach and Nectarine), $P$. armeniaca (Apricot), $P$. domestica (European Plum), $P$. salicina (Japanese Plum), other plum species, and $P$. avium (Sweet Cherry) are grown in orchards and gardens for their fruit, and $P$. dulcis (Almond) for its seeds. P. cerasifera (Cherry Plum), P. cerasus (Sour Cherry) and probably Prunus sp. 'a' have been widely used as rootstocks for grafts of fruit-bearing Prunus. Many species, including purple-foliaged forms of $P$. cerasifera, the evergreen species $P$. laurocerasus (Cherry Laurel) and $P$. lusitanica (Portuguese Laurel), P. serotina (Black Cherry) and flowering varieties of several other species and hybrids, are grown as ornamental trees and shrubs. P. mahaleb (St Lucie's Cherry) is useful as a rootstock for $P$. avium.

Wild individuals appear to arise through seed dispersal by people (in those species grown for their fruit); through dispersal by birds (for smaller-fruited species); or through vegetative reproduction by suckers.

A study of roadside alien trees and shrubs taller than one metre in New England (Smith 1982a, 1982b) found beside $1193 \mathrm{~km}$ of surveyed roads 163 Peaches and Nectarines ( $P$. persica), 118 Plums (mostly $P$. cerasifera with a few $P$. domestica and $P$. salicina) and 42 Apricots ( $P$. armeniaca). These and other fruit trees (the commonest of all being Apple, Malus domestica) were most frequent beside the busiest roads, and it was inferred that they were mostly derived from seeds discarded as fruit wastes by vehicle passengers. The only fruit tree that apparently regularly regenerated in situ from its own seed (though some wild roadside individuals of most species fruited at least occasionally), as indicated by 'mother and babies' clumps, was Prunus cerasifera. This was also the species that showed the relationship between roadside abundance and traffic volume least clearly. Trees of $P$. persica were found in the same study to be tallest in areas with highest minimum temperatures.

In a further study (Smith 1985) of alien trees and shrubs taller than one metre along a main road transect between Wyong (north of Sydney) and Ipswich (south-west of Brisbane) through New England, Prunus armeniaca was found to be tallest and most abundant in southern Queensland, while $P$. persica was most abundant in areas south of New England. Both failed to grow as tall at high altitudes as in lower areas to both north and south, but both were absent from the Queensland coastal plain near Ipswich. Plums showed less clear patterns perhaps due to two species (Prunus cerasifera and $P$. salicina) not being distinguished. $P$. domestica subsp. domestica, $P$. avium and $P$. cerasus occurred sporadically at high altitudes.

Prunus species with smaller fruits are not particularly associated with roadside habitats, and to a degree this is also true of $P$. cerasifera. In this they resemble other alien woody plants with small fleshy fruits (e.g. species of Cotoneaster, Crataegus, Ligustrum and Pyracantha) all of which are probably dispersed by birds, especially currawongs (Strepera spp.). Such species tend to 
grow within several kilometres of centres of European settlement (Mulvaney 1984; Smith 1982a, 1985), where parental trees were planted in hedges and gardens, and whence birds have spread their seeds. $P$. mahaleb is becoming naturalized at a site near Armidale and $P$. serotina at Leura. $P$. laurocerasus is already common in the Robertson area and in parts of the Blue Mountains. $P$. lusitanica has been collected once, away from roads but near gardens in the Blue Mountains.

Three Prunus taxa appear to regenerate only vegetatively, by suckers, forming dense thicket-like colonies marking the sites of abandoned orchards, cottages and similar locations of original plantings. All are fruit trees ( $P$. domestica subsp. domestica and subsp. insititia, and $P$. cerasus), the last probably having been planted more as a rootstock for grafted sweet cherries than in its own right. Other alien woody plants with similar reproductive characteristics show similar patterns, such as species of Chaenomeles, Populus, and Ulmus.

It is of interest to speculate why alien woody species such as these, many of which occur frequently as wild individuals, have been collected so infrequently, and largely ignored by the writers of floras. Wace (1978) defines a naturalized plant as 'one that grows and reproduces for several generations at least, without the direct aid of man, outside its native range'. No Prunus species can properly be described as naturalized by this definition because barely sufficient time has elapsed since their introduction to allow the passage of several generations. Possibly this explains their having been neglected by botanists, although lack of interest in the collection and study of aliens compared with natives seems a more likely explanation.

Wace's definition of a naturalized plant seems impractical for woody species with a long life-cycle. An alternative may be to define as being in the process of naturalization those species whose populations outside their native range include large proportions of young individuals, not solely restricted to the immediate vicinity of parental individuals, without having received direct human assistance. Woody plants, which are generally large and conspicuous and whose size is generally proportional to their age, can readily be assessed in this way.

According to this definition, $P$. cerasifera is certainly in the process of naturalization, and $P$. laurocerasus, $P$. mahaleb, $P$. serotina and probably $P$. persica can be considered so on a local scale. $P$. armeniaca, $P$. salicina and probably $P$. avium, whose populations appear to be entirely dependent upon seeds discarded by people; those taxa that regenerate only by suckering; and $P$. domestica subsp. italica (Greengage), $P$. dulcis, $P$. lusitanica and $P$. sp. 'a' (if distinct from $P$. cerasifera) which are rare, cannot be considered as 'being now in the process of naturalization. They may, of course, become so in future, as may other species that are yet to be collected or recorded as wild individuals but which have been, or will be, planted in gardens or elsewhere.

\section{Phenology}

Except for $P$. laurocerasus and $P$. lusitanica, species in New South Wales are deciduous, the flowers opening before the leaves, and flowering generally being completed before any leaves are fully extended. The timing of budburst in spring varies with the seasons to some extent, but also varies between species, as indicated by some data from wild individuals in and near Armidale (Fig. 1). 
Prunus species flower between July and October in the Armidale area. $P$. dulcis is the earliest flowering species, followed closely by $P$. cerasifera, $P$. salicina, $P$. armeniaca and $P$. persica. Latest flowering species are $P$. mahaleb and $P$. domestica. The latter flowers about a month later than the other plums, scarcely overlapping with them, which (as well as its different chromosome number) may restrict possibilities of hybridisation between $P$. domestica and other species in subgenus Prunus.

$P$. cerasifera and $P$. salicina, at least, may suffer frost damage to flowers or young fruits in some years, and carry no fruits to maturity in the Armidale area and presumably elsewhere at high altitudes. Frost may also explain the apparent inability to set fruit of the only wild individual of $P$. dulcis observed, in a frostprone location beside a floodplain. A similar inability exhibited by $P$. avium may be due to the rarity of wild individuals of this species, and the remoteness of those observed from conspecific trees in orchards or elsewhere, since they are obligate cross-pollinators. $P$. avium can hybridise with $P$. cerasus, this being the origin of some cherry cultivars. The two species overlap in flowering periods, but that of $P$. avium begins 2-3 weeks earlier than $P$. cerasus.

Prunus flowers are insect-pollinated; they may be fragrant, and many insects can be seen to visit them.

Fruiting periods also differ between species (Fig. 1). P. cerasifera ripens its fruits earliest, though individuals vary, so that ripe fruits can readily be found

\begin{tabular}{|l|l|l|l|l|l|l|l|l|l|l|l|}
\hline \multicolumn{1}{|c|}{ SPECIES } & YEAR & J & J & A & S & O & N & D & J & F & M \\
\hline P. persica & 1982 & & & & & & & & & & \\
\hline P. persica & 1983 & & & & & & & & & & \\
\hline P. dulcis & 1982 & & & & & & & & & & \\
\hline P. dulcis & 1983 & & & & & & & & & & \\
\hline P. armeniaca & 1982 & & & & & & & & & & \\
\hline P. armeniaca & 1983 & & & & & & & & & & \\
\hline P. cerasifera & 1982 & & & & & & & & & & \\
\hline P. cerasifera & 1983 & & & & & & & & & & \\
\hline P. d. domestica & 1982 & & & & & & & & & & \\
\hline P. d. domestica & 1983 & & & & & & & & & & \\
\hline P. d. insititia & 1983 & & & & & & & & & & \\
\hline P. salicina & 1983 & & & & & & & & & & \\
\hline P. mahaleb & 1983 & & & & & & & & & & \\
\hline
\end{tabular}

Fig. 1. Times of flowering (July-October) and fruiting (December-February) of some wild individuals of species of Prunus growing near Armidale. 
throughout a period of six weeks in years without late, damaging frost. $P$. domestica and $P$. persica are those species whose fruits ripen latest in summer.

\section{Plum taxonomy}

Most Prunus species occurring as wild plants in New South Wales are taxonomically distinct. However, this is not so for the plums, of which at least three species ( $P$. cerasifera, $P$. domestica, and $P$. salicina) occur as wild individuals, with possible hybrids. Details of ploidy, hybridisation and ancestry of plums reported below come mainly from abstracted data in Knight (1969).

$P$. domestica is a variable, hexaploid species which is itself believed to be of hybrid origin, derived from $P$. cerasifera (usually diploid) and $P$. spinosa (usually tetraploid).

Japanese plums are usually grouped under $P$. salicina (normally diploid), but some have hybrid origin. Of the cultivars grown in Australia listed by Ikin (1974) as 'Japanese and American hybrids' about a quarter are believed not to be pure $P$. salicina. One cultivar each of the American species $P$. angustifolia ('Chickasaw') and $P$. munsoniana ('Wild Goose') are recorded as being cultivated in Queensland, and the cultivar 'Beaty' (Western Australia and Victoria) may be a hybrid between these species. The widely grown cultivar 'Santa Rosa' is a complex hybrid between $P$. salicina, the Chinese species $P$. simonii, and $P$. americana. Other cultivars in Australia may be hybrids involving further American species: $P$. hortulana ('Excelsior', 'Formosa'), $P$. nigra ('Patterson Pride') and $P$. maritima ('Shipper'), though the ancestry of these and other cultivars is not entirely clear. The diploid $P$. cerasifera can also hybridize with $P$. salicina and this may be the origin of the widely grown cultivar 'Billington'. Both $P$. cerasifera and $P$. salicina can also produce tetraploid hybrids with $P$. domestica, with higher ploidy levels common in the subsequent generation. Most cultivated, ornamental purple-foliaged trees belong to $P$. cerasifera; Lord (1964) mentions four such cultivars, the commonest being 'Atropurpurea' (= 'Pissardii') and 'Nigra'. The similar but double-flowered ' $P$. blireiana' is a hybrid between $P$. cerasifera 'Atropurpurea' and the Japanese $P$. mume.

It is not surprising, therefore, that it is not always easy to allocate species names to individual wild plum trees. It might even be anticipated that any attempt would be nearly futile, were it not for the experience that most can, in fact, be identified with some confidence, intermediates being exceptional. Most (more than $95 \%$ in New England) belong to $P$. cerasifera, including all maroonfoliaged individuals. $P$. salicina and $P$. domestica both occur infrequently. All three species are common and widespread in cultivation in New South Wales. Ikin (1974) lists 77 cultivars of $P$. domestica and 47 of 'Japanese and American hybrids' present in Australia. $P$. cerasifera is also grown for its fruit (two or three cultivars, though not listed for New South Wales) but is used more widely as a rootstock for grafts of other plums, and as a garden ornamental and street tree.

Infraspecific taxonomy of Prunus domestica is confused. Wild plants in New South Wales include a range of unarmed, suckering, shrubby, purple-fruited forms, which I call here subsp. domestica, except for one with distinctly small, ovoid and mildly astringent fruits and hirsute young twigs which I call subsp. insititia (Damson); there is also an armed, non-suckering, small tree with green, very sweet fruits that I call subsp. italica (Greengage). 


\section{The New South Wales species}

Each Prunus species recorded wild in New South Wales is described, and a key to the species, subspecies and varieties is provided, below.

All data in the species descriptions derive from specimens collected wild in New South Wales. They differ at times in detail from descriptions of the same species in Floras of north temperate regions. This may be due to the influence of local climatic or other conditions on phenotypes, to there being a dearth of old plants, to only a limited genetic range being represented, or possibly to doubtful identifications in some cases.

It is also partly due to only a limited number of specimens having been collected, and therefore studied, in New South Wales. Some descriptions are incomplete because of inadequate material from wild plants being available. Further details can readily be obtained from Floras and other botanical works pertaining to north temperate regions.

All specimens referred to are lodged in the National Herbarium of New South Wales. Where two or more specimen numbers and dates are separated by slashes, they refer to specimens collected at different times from the same individual plants.

\section{Key to species, subspecies and varieties of Prunus found in New South Wales}

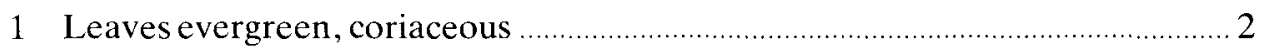

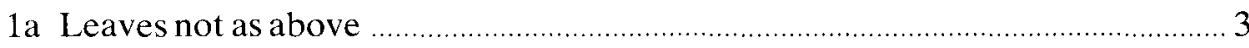

2 Leaves not exceeding $8 \mathrm{~cm}$ long, with serrate margin .................. 12. P. Iusitanica

2a Leaves up to $13 \mathrm{~cm}$ long, margin with only distant, small teeth

13. P. laurocerasus

3 Inflorescence a raceme more than $8 \mathrm{~cm}$ long with more than 10 flowers

11. P. serotina

3a Inflorescence a raceme less than $3 \mathrm{~cm}$ long with fewer than 10 flowers

10. P. mahaleb

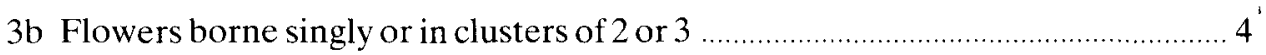

4 Leaves mostly lanceolate; petals pink ................................................................. 5

4a Leaves mostly ovate; petals white (or if pink then leaves are maroon) ................. 7

5 Petals uniformly pink or dark pink; sepals reflexed in open flower to

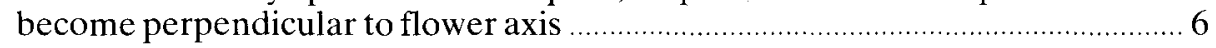

5a Petals pale pink, darker only at base; sepals not reflexed .................... 2. P. dulcis

6 Fruit velutinous

1a. P. persica var. persica

6a Fruit glabrous

1b. P. persica var. nucipersica

7 Fruits less than $2 \mathrm{~cm}$ long; petioles with glands ............................................... 8

7a Fruits more than $2 \mathrm{~cm}$ long; petioles lacking glands ....................................... 9

8 Tree with few or no suckers; leaves up to $12 \mathrm{~cm}$ long ........................ 8. P. avium

$8 \mathrm{a}$ Shrub with abundant suckers; leaves not exceeding $6 \mathrm{~cm}$ long .......... 9. P. cerasus 
9 Flowers sessile; fruit velutinous; leaves broadly ovate with rounded or cordate base

3. P. armeniaca

9a Flowers pedicellate; fruit glabrous; leaves ovate or elliptical with cuneate base

10 Ripe fruits purple or green; winter buds conical; leaves usually glossy above with veins prominently raised below

10a Ripe fruits red or yellow; winter buds ovoid, sometimes with acute tip; leaves not as above

11 Ripe fruits purple; mesocarp red; unarmed; abundant suckers 12

11a Ripe fruits green; mesocarp yellow; stout spines; no suckers

\section{5c. P. domestica subsp. italica}

12 Fruits globose; leaves up to $7 \mathrm{~cm}$ long; first-year twigs glabrous or nearly so 5a. P. domestica subsp. domestica

12a Fruits ovoid; leaves not exceeding $4 \mathrm{~cm}$ long; first-year twigs hairy

5a. P domestica subsp. insititia

13 Fruits over $3 \mathrm{~cm}$ long; mesocarp orange or red; winter buds with acute tip; leaves often becoming red above 6. P. salicina

13a Fruits less than $3.5 \mathrm{~cm}$ long; mesocarp yellow (or if red then leaves are maroon); winter buds with obtuse tip; leaves green or maroon 14

14 Erect tree or shrub, especially when young, often with stout spines; flowers mostly borne singly

4. P. cerasifera

14a Broadly spreading unarmed shrub; flowers borne in pairs

7.P.sp. 'a'

Subgen. Amygdalus (L.) Focke

\section{Prunus persica (L.) Batsch (Peach, Nectarine)}

Shrub or small tree to $4 \mathrm{~m}$, rather erect but sometimes becoming spreading with age; suckers absent; first-year twigs $2-4 \mathrm{~mm}$ thick, green or reddish brown; winter buds ovoid, $3 \mathrm{~mm}$ long, bud-scales reddish brown but appearing grey because hirsute, especially distally; leaves deciduous, green, 5-13 cm long, c. 4 times as long as wide, lanceolate with acute tip and serrulate margin (teeth $<$ $0.5 \mathrm{~mm}$ ), glabrous, tending to be recurved; petioles $5-10 \mathrm{~mm}$; flowers sessile or nearly so, borne singly; sepals maroon or sometimes green, tomentose, $4 \mathrm{~mm}$ long, held perpendicular to flower axis when flower is open; petals pink, 13-17 mm long, 10-14 $\mathrm{mm}$ wide, or dark pink, 8-9 $\mathrm{mm}$ long, 5-6 mm wide; anthers maroon; filaments pink or white (or rarely pink, petaloid and lacking anthers); fruit globose, green, becoming red especially where unshaded; mesocarp green or yellow, sweet; endocarp coarsely pitted and ridged. Ebor, $J M B S$, Sep. 1983; Guyra, JMBS 702, Sep. 1982; Kangaroo Valley, J.A. Rodway, s.n., Aug. 1917; Willow Tree, JMBS 713, Sep. 1982.

\section{1a. var. persica (Peach)}

Fruit 4-5 cm diameter, velutinous; endocarp 25-30 mm long, 20-25 mm wide. Armidale, JMBS 858, Jan. 1984; Wellington, L.A.S. Johnson \& B.G. Briggs 8222, Nov. 1975. 


\section{1b. var. nucipersica (Borkh.) C.K. Schneider (Nectarine)}

Fruit 3-4 cm diameter, glabrous, often with maroon spots; endocarp 20-25 mm long, 16-20 mm wide. Guyra, JMBS 852, Jan. 1984.

$P$. persica is native to China or Central Asia (possibly of cultivated origin); widespread and frequent in eastern New South Wales, especially beside roads and in moister, warmer areas, apparently becoming naturalized on some sandy riverbanks, e.g. Glen Fernaigh Creek near Bostobrick, Dorrigo Plateau.

\section{Prunus dulcis (Miller) D.A. Webb (Almond)}

Small tree to $3 \mathrm{~m}$; suckers absent; unarmed; shoots tend to lean to northwest (afternoon sun); first-year twigs 2-3 mm thick, green; winter buds 2-2.5 $\mathrm{mm}$ long, ovoid, bud-scales reddish brown and conspicuously mucronate; leaves deciduous, green, $3-6 \mathrm{~cm}$ long, more than twice as long as wide, glabrous, lanceolate to ovate with acute tip and serrulate margin (teeth $0.5 \mathrm{~mm}$ ); petioles $8-10 \mathrm{~mm}$; flowers sessile, borne singly or in pairs; sepals green, tinged maroon, with long marginal hairs, 2-2.5 $\mathrm{mm}$ long, not reflexed; petals very pale pink, darker at base, $15 \mathrm{~mm}$ long, $15 \mathrm{~mm}$ wide; anthers yellow; filaments pink; fruit not seen. Armidale, JMBS 695/837, Sep. 1982/Jan. 1984.

Native to central and south-west Asia and north Africa. Rare as a wild plant in New South Wales, known only from one individual in Armidale growing on a roadside bank where garden refuse may have been discarded.

\section{Subgen. Prunus}

\section{Prunus armeniaca L. (Apricot)}

Shrub to $3 \mathrm{~m}$, spreading habit; suckers absent; unarmed; first-year twigs 2-3 mm thick, brown; winter buds conical or ovoid with acute tip, dark brown, $2 \mathrm{~mm}$ long; leaves deciduous, green, glabrous, $3-5 \mathrm{~cm}$ long, about as wide as long, broadly ovate with rounded to cordate base, acute to acuminate tip, and serrulate margin (teeth $0.5 \mathrm{~mm}$ ); petioles $20-40 \mathrm{~mm}$; flowers sessile, borne singly; sepals maroon, becoming paler at their united bases, hirsute, 4-5 mm long, reflexed when flower is open; petals white, often pink at base, $7-13 \mathrm{~mm}$ long, $8-15 \mathrm{~mm}$ wide; anthers yellow; filaments white becoming pink with age; fruit globose, 4-5 cm diameter, orange, velutinous; mesocarp orange, sweet, not adhering to endocarp; endocarp rugose, $18 \mathrm{~mm}$ long, $18 \mathrm{~mm}$ wide. Armidale, JMBS 794/857, Sep. 1983/Jan. 1984; Ben Lomond, JMBS 706, Sep. 1982; Muswellbrook, F. Liddell s.n., Mar. 1913; Tenterfield, JMBS 814, Nov. 1984.

Native to central Asia and China. Widespread and frequent beside roads in eastern New South Wales.

\section{Prunus cerasifera Ehrh. (Cherry Plum)}

Shrub or tree to $4 \mathrm{~m}$ tall, rather erect with crown not as wide as it is tall especially when young; suckers apparently absent but often many seedlings present; may have stout spines on lower branches; first year twigs $1.5-2.5 \mathrm{~mm}$ thick, greenish or dark brown; winter buds ovoid, sometimes with acute tip, $1 \mathrm{~mm}$ long; leaves deciduous, green (often reddish when young) or maroon, $2.5-5 \mathrm{~cm}$ long, less than twice as long as wide, ovate to elliptical with serrulate margin (teeth $0.5 \mathrm{~mm}$ long) and acute tip; flowers mostly borne singly, some in pairs; pedicels 5-15 mm long, green or maroon; sepals green (sometimes tinged 
pink) or maroon, with translucent pink margin, shortly hairy, $2 \mathrm{~mm}$ long; petals white (sometimes with pale pink base), or pale pink (in maroon-foliaged plants) 5-10 mm long, 4-9 mm wide; anthers yellow, orange or dark red; filaments white or pink (or rarely petaloid, pale pink and lacking anthers); fruit globose, 2-3 cm diameter, red or yellow; mesocarp yellow (or red in maroon-foliaged plants), sweet, sour or insipid; endocarp 12-17 $\mathrm{mm}$ long, 8-10 $\mathrm{mm}$ wide, smooth sometimes with longitudinal ridges, with obtuse ends. Armidale, JMBS 697, Sep. 1982, JMBS, Jan. 1984, JMBS 844, Jan. 1984; Guyra, JMBS 712, Sep. 1982; Kangaroo Valley, F.A. Rodway 2004A/2004B, Aug. 1934/Nov. 1935.

Native to the Balkan Peninsula, Turkey and the Caspian region. Widespread in eastern New South Wales, common on roadsides and in other places with past but not frequently repeated disturbance, especially near towns. Frequently clumped, with many seedlings and saplings around a large parental tree, often with different leaf or fruit colours.

\section{Prunus domestica L. (European Plum, Greengage, Damson)}

Shrub or tree to $4 \mathrm{~m}$ tall, usually with spreading crown; winter buds conical; leaves deciduous, green, with serrate margin (teeth $1 \mathrm{~mm}$ long) and acute tip, glossy above and paler, pubescent and sometimes glaucous below, veins prominently raised on lower lamina; flowers mostly borne in pairs, sometimes singly, or rarely in threes; pedicels $4-8 \mathrm{~mm}$, green; sepals 2-3 mm long, sparsely hirsute, green with a translucent colourless or pale pink margin; petals white, 8-10 $\mathrm{mm}$ long, 6-8 $\mathrm{mm}$ wide; anthers yellow; filaments white; endocarp with longitudinal ridges or irregularly rugose, with acute or obtuse ends.

\section{5a. subsp. domestica (European Plum)}

Freely suckering; unarmed; first-year twigs $2-3 \mathrm{~mm}$ thick, grey-brown, glabrous or nearly so; leaves $3-7 \mathrm{~cm}$ long, $1.5-4.5 \mathrm{~cm}$ wide, ovate; fruit globose, 25-35 mm diameter, purple; mesocarp yellow or red, sweet; endocarp $20 \mathrm{~mm}$ long, 14 mm wide. Armidale, JMBS 808/863, Sep. 1983/Jan. 1984; Guyra, JMBS 853, Jan. 1984.

\section{5b. subsp. insititia (L.) C.K. Schneider (Damson)}

Freely suckering; unarmed; first-year twigs $1.5-2.5 \mathrm{~mm}$ thick, grey-brown, with many short hairs; leaves $1.5-4 \mathrm{~cm}$ long, $1-1.8 \mathrm{~cm}$ wide, ovate to elliptical; fruit ovoid, $20 \mathrm{~mm}$ long, $17 \mathrm{~mm}$ wide, purple with pronounced bloom; mesocarp red, sweetish but mildly astringent; endocarp $20 \mathrm{~mm}$ long, $14 \mathrm{~mm}$ wide. Armidale, JMBS 720/862, Oct. 1982/Jan. 1984.

\section{5c. subsp. italica (Borkh.) Hegi (Greengage)}

No suckers; some stout spines, especially on lower branches; first-year twigs 1.5-2 mm thick, grey, glabrous or nearly so; winter buds $1-1.5 \mathrm{~mm}$ long; leaves 2.5-8 cm long, obovate; petals may be tinged pink distally in opening bud; fruit globose, $25 \mathrm{~mm}$ diameter, green; mesocarp yellow; sweet; endocarp 18-20 mm long, $12 \mathrm{~mm}$ wide. Bostobrick, JMBS 741/793/836, Dec. 1982/Sep. 1983/Dec. 1983.

P. domestica is of hybrid origin, probably in the Caucasus region. In New South Wales, subsp. domestica frequently grows at high altitudes as suckering 
clumps near houses, in abandoned orchards and similar places; subspp. insititia and italica are rare, known only from a single suckering clump in a paddock near Armidale and a single roadside tree near Bostobrick, Dorrigo Plateau, respectively.

\section{Prunus salicina Lindl. (Japanese Plum)}

Shrub or tree to $4 \mathrm{~m}$ tall, crown spreading and about as wide as tall; apparently not suckering though a few seedlings may be present; may have stout spines, especially when young or on lower branches; first-year twigs $1.5-3 \mathrm{~mm}$ thick, reddish brown; winter buds ovoid with acute tip, $1 \mathrm{~mm}$ long; leaves deciduous, green, sometimes becoming reddish on upper surface, $3-6 \mathrm{~cm}$ long, more than twice as long as wide, elliptical to lanceolate with serrulate margin (teeth $0.5 \mathrm{~mm}$ ) and acute to acuminate tip; flowers mostly borne in pairs, sometimes singly or in threes; fruit globose, $30-40 \mathrm{~mm}$ diameter, dark red; mesocarp orange or red, sweet; endocarp 17-21 mm long, 10-24 mm wide, smooth, sometimes with longitudinal ridges, and with acute ends. Armidale, JMBS 699/846, Sep. 1982/Jan. 1984, JMBS 790/859, Sep. 1983/Jan. 1984.

Native to China and Japan. In New South Wales it occurs infrequently beside roads in New England and probably in other regions.

\section{Prunus sp. ' $a$ '}

Similar to $P$. cerasifera, of which it may be a form or hybrid. Shrub to $3 \mathrm{~m}$, spreading, crown wider than tall; few or no suckers; unarmed; first-year twigs 1.5-2 mm thick, reddish brown; buds ovoid with acute tip, dark brown, $1.5 \mathrm{~mm}$ long; leaves deciduous but sometimes persisting to late winter, green, $3-3.5 \mathrm{~cm}$ long, about twice as long as wide, ovate with acute to obtuse tip and serrulate margin (teeth $>0.5 \mathrm{~mm}$ ); petioles $8-12 \mathrm{~mm}$; flowers borne in pairs; pedicels 5-7 mm; sepals $1 \mathrm{~mm}$ long, green with translucent pale pink margin with sparse marginal hairs; petals white, $5 \mathrm{~mm}$ long, $5 \mathrm{~mm}$ wide; anthers yellow; filaments white; fruit ovoid, $34 \mathrm{~mm}$ long, $25 \mathrm{~mm}$ wide, red; mesocarp yellow, insipid; endocarp $20 \mathrm{~mm}$ long, $15 \mathrm{~mm}$ wide, with shallow pitting. Armidale, JMBS 694/ 861, Sep. 1982/Jan. 1984.

Rare, known from three individuals on roadsides near houses at separate locations near Armidale.

\section{Subgen. Cerasus (Miller) Focke}

\section{Prunus avium L. (Sweet Cherry)}

Tree to $6.5 \mathrm{~m}$; few or no suckers; unarmed; bark tends to peel in horizontal papery strips; first-year twigs $2-3 \mathrm{~mm}$ thick, grey-brown; winter buds $3-4 \mathrm{~mm}$ long, ovoid with acute to obtuse tip, reddish brown; leaves deciduous, green, $4-12 \mathrm{~cm}$ long, nearly twice as long as wide, elliptical to ovate with acute to acuminate tip and serrate margin (teeth $1-1.5 \mathrm{~mm}$ ), glabrous above, paler with hairs below; petioles $10-30 \mathrm{~mm}$, reddish green with one or two brown glands distally; pedicels $2-8 \mathrm{~mm}$ (when flowering); flowers borne singly or in pairs; sepals green, glabrous, reflexed in open flower, $3 \mathrm{~mm}$ long; petals white, $10 \mathrm{~mm}$ long, 7-8 $\mathrm{mm}$ wide; anthers yellow; filaments white; fruit not seen. Ebor, $J M B S$ 803/854, Sep. 1983/Jan. 1984. 
Native to Europe and West Asia. In New South Wales infrequent on roadsides at high altitudes.

\section{Prunus cerasus L. (Sour Cherry)}

Shrub to $3.5 \mathrm{~m}$; abundant suckers; unarmed; first-year twigs $1.5-2 \mathrm{~mm}$ thick, reddish brown or grey-brown; winter buds $2 \mathrm{~mm}$ long, reddish brown; leaves deciduous, green, 3-6 cm long, about twice as long as wide, elliptical to obovate, with obtuse to acute tip and serrate margin (teeth $1-1.5 \mathrm{~mm}$ ), glabrous above, paler with hairs below, with brown gland on margin near petiole; petioles $10-15 \mathrm{~mm}$, green or reddish; pedicels $6-8 \mathrm{~mm}$ (in flower) or 15-22 mm (in fruit); flowers borne in pairs, sometimes singly or in threes; sepals green with reddish tinge, glabrous, $3 \mathrm{~mm}$ long; petals white, $8-12 \mathrm{~mm}$ long, $7-12 \mathrm{~mm}$ wide; anthers yellow; filaments white; fruit globose, $10-15 \mathrm{~mm}$ diameter, green ripening to red. Guyra, JMBS 811, Nov. 1983; Uralla, JMBS 873, Oct. 1984; Wallabadah, JMBS 731, Nov. 1982.

Native to south-west Asia. In New South Wales grows infrequently in eastern areas as suckering clumps, usually on sites of old orchards or gardens.

\section{Prunus mahaleb L. (St. Lucie's Cherry)}

Tree or large shrub to $4.5 \mathrm{~m}$ tall with spreading habit; suckers absent but with numerous seedlings below old trees; unarmed; first-year twigs 1-2 mm thick, pale grey; winter buds ovoid, reddish brown, $2 \mathrm{~mm}$ long; leaves green, deciduous, $1.5-3.5 \mathrm{~cm}$ long, $1-2.5 \mathrm{~cm}$ wide, ovate with rounded base, acute tip and crenulate margin; petioles slender, $4-8 \mathrm{~mm}$; flowers borne in racemes of 4-10 flowers, on pedicels $8-12 \mathrm{~mm}$ and peduncles $15-25 \mathrm{~mm}$ long, both green; sepals green, glabrous, reflexed when flower is open, $2 \mathrm{~mm}$ long; petals white, 3-7 mm long, 2-4 mm wide; anthers yellow; filaments white; fruit globose, $8 \mathrm{~mm}$ long, $9 \mathrm{~mm}$ wide, red ripening to black, bitter; endocarp smooth, globose, 4-5 mm diameter. Armidale, JMBS 722/809/842, Oct. 1982/Sep. 1983/Jan. 1984.

Native to central and southern Europe. In New South Wales, occurring as a small, expanding population in a pine plantation near Armidale.

\section{Subgen. Padus (Miller) Focke}

\section{Prunus serotina Ehrh. (Black Cherry)}

Shrub or tree to $13 \mathrm{~m}$ tall with straight trunk; suckers absent; unarmed; leaves green, deciduous, $4-11 \mathrm{~cm}$ long, $2.5-4 \mathrm{~cm}$ wide, ovate-lanceolate with serrulate margin (teeth $0.5 \mathrm{~mm}$ ) and acute tip, rusty-hirsute beside proximal half of raised midrib on lower surface; flowers (not seen) borne in racemes of c. 20; peduncles $80-110 \mathrm{~mm}$; pedicels $4-6 \mathrm{~mm}$; fruit spheroidal, green tinged red, becoming black and soft when ripe, $8-10 \mathrm{~mm}$ diameter; mesocarp purplish black, sweetish and slightly astringent; endocarp $6 \mathrm{~mm}$ long, $5 \mathrm{~mm}$ wide, ovoid, slightly flattened, obtuse at both ends, smooth. Leura, L.A.S. Johnson s.n., Dec. $1959 ; J M B S$ 884, Feb. 1985.

Native to eastern North America. In New South Wales known wild only at Leura and Katoomba, Blue Mountains, becoming frequent beside paths and roads in shrubland and disturbed eucalypt forest on sandstone (probably derived from planted trees at 'Leuralla'). 
Subgen. Laurocerasus (Duh.) Rehder

\section{Prunus lusitanica L. (Portuguese Laurel)}

Young plant a shrub $1.5 \mathrm{~m}$ tall; young twigs very dark reddish, 1-2 mm thick; leaves not deciduous, coriaceous, $5-8 \mathrm{~cm}$ long, ovate to lanceolate with acuminate tip and serrate margin (teeth $1 \mathrm{~mm}$ ). Flowers and fruit not seen. Mt Wilson, D. Blaxell s.n., Dec. 1958.

Native to Portugal, Canary Islands and Madeira. Collected once at Mt. Wilson, Blue Mountains, as a sterile shrub in rainforest on basalt (apparently from seed from gardens on Mt. Wilson)'.

\section{Prunus laurocerasus L. (Cherry Laurel)}

Shrub or spreading multistemmed tree to $10 \mathrm{~m}$ tall; no suckers; unarmed; young twigs reddish, $3-4 \mathrm{~mm}$ thick; leaves not deciduous, green, very coriaceous, $5-13 \mathrm{~cm}$ long, $2-5 \mathrm{~cm}$ wide, with acute tip and finely and distantly toothed margin; flowers shortly pedicellate in racemes $10-13 \mathrm{~cm}$ long, each of 10-20 flowers; petals white; fruits ovoid and bluntly pointed (obpyriform), 15-17 mm long, 11-14 mm wide, green tinged red, becoming black and soft when ripe; mesocarp yellow-brown, sweetish; endocarp ovoid, not conspicuously flattened, $12 \mathrm{~mm}$ long, $7 \mathrm{~mm}$ wide, with acute ends, smooth. Mt Wilson, JMBS 879, Feb. 1985; Robertson, R. Pullen 3899, Oct. 1963, JMBS 888, Feb. 1985.

Native to the Balkan Peninsula, Turkey, Armenia and north Iran. Becoming naturalised within a $5 \mathrm{~km}$ radius of Robertson on roadsides and in degraded remnants of eucalypt forest; and in higher parts of the Blue Mountains (Katoomba, Mt. Tomah, Mt. Wilson) on roadsides and in tall eucalypt forest with rainforest understorey.

\section{Acknowledgements}

I am grateful to A.N. Rodd, N.M. Wace and K.L. Wilson for their encouragement and constructive comments during preparation of this paper.

\section{References}

Anderson, R.H. (1939) The naturalised flora of New South Wales (excluding Gramineae). Contr. New South Wales Natl Herb. 1: 16-33.

Beadle, N.C.W. (1976) 'Students Flora of North Eastern New South Wales'. Part 3. Angiosperms: Families 84-106 (Dept Bot., Univ. New England: Armidale).

Beadle, N.C.W., Evans, O.D., \& Carolin, R.C. (1972). 'Flora of the Sydney Region'. Edn 2 (A.H. \& A.W. Reed: Sydney).

Burbidge, N.T., \& Gray, M. (1970) 'Flora of the Australian Capital Territory'. (Austral. Natl Univ. Press: Canberra).

Curtis, W.M. (1956) 'The Student's Flora of Tasmania'. Part 1 (Govt Printer: Hobart).

Eichler, Hj. (1965) 'Supplement to J.M. Black's Flora of South Australia' (Govt Printer: Adelaide).

Ikin, R. (1974) 'Varieties of Fruit Trees, Berry Fruit, Nuts and Vines in Australia'. (Austral. Govt Publ. Service: Canberra.)

Jacobs, S.W.L., \& Pickard, J. (1981) 'Plants of New South Wales. A census of the Cycads, Conifers and Angiosperms' (Govt Printer: Sydney).

Knight, R.L. (1969) 'Abstract Bibliography of Fruit Breeding and Genetics to 1965. Prunus' (Comm. Agric. Bureau: Farnham Royal, England). 
Lord, E.E. (1964) 'Shrubs and Trees for Australian Gardens' (Lothian: Melbourne).

Mulvaney, M. (1984) 'The Distribution, Ecology and Weed Potential of Naturalised Species of Cotoneaster and Pyracantha within the Canberra Region' (Hons. Thesis, Dept Bot., Austral. Natl Univ.: Canberra).

Smith, J.M.B. (1982a) 'Establishment of Exotic Woody Plants along Roadsides in New England (New South Wales)' (Dept Geog., Univ. New England: Armidale).

Smith, J.M.B. (1982b) Naturalised fruit trees on New England roadsides. Search 13: 207-208.

Smith, J.M.B. (1985) Exotic trees and shrubs along a roadside transect between Sydney and Brisbane. Austral. Geographer 16: 264-271.

Tutin, T.G., Heywood, V.H., Burges, N.A., Moore, D.M., Valentine, D.H., Walters, S.M., \& Webb, D.A. (1968) 'Flora Europea'. Vol. 2. Rosaceae to Umbelliferae (Cambridge Univ. Press: Cambridge).

Wace, N.M. (1978) Human modification of the natural ranges of plants and animals. Pp. 225-244 in D. Walker \& J.C. Guppy (eds), 'Biology and Quaternary Environments' (Austral. Acad. Sci.: Canberra).

Willis, J.C. (1966) 'A Dictionary of the Flowering Plants and Ferns'. Edn 7 rev. H.K. Airy Shaw (Cambridge Univ. Press: Cambridge).

Willis, J.H. (1972) 'A Handbook of Plants in Victoria'. Vol. 2 (Melbourne Univ. Press: Melbourne).

Manuscript received 31 May 1985

Manuscript accepted 11 June 1986 